\title{
Drama in Chalk and Talk Classrooms
}

\author{
Ruwaida Abu Rass \\ The Academic Institute for Arab Teacher Training in the Academic, College Beit Berl, Israel \\ Email: aburass@beitberl.ac.il
}

\begin{abstract}
This paper describes two attempts of preparing Arab junior high school pupils to perform on the stage by Arab female student teachers who are pursuing their teaching practice in traditional Arab classrooms in the center of Israel. Following the pedagogical adviser's initiative, the student teachers trained two groups of junior high school pupils to perform a play and an episode of another one on the stage: Joseph and The Lion King. At the beginning, the trainees didn't show enthusiasm. In fact, they were reluctant to participate claiming that the pupils won't learn their roles, or they won't be serious enough. They might be shy to perform on the stage wearing special clothes. However, when they started the rehearsal, they were more than eager to follow the pupils' performance. They even concluded that the experience was exciting and satisfying, yet it is not easy to copy it and to try it.
\end{abstract}

Index Terms - traditional Arab classrooms, student teachers, trainees, drama, dramatic activities

\section{INTRODUCTION}

Employing drama and dramatic activities makes learning an enjoyable experience, makes the communicative experience more real and link it with the student's own experience of life (Royka, 2002). Drama also "gives a context for listening and meaningful language production, forcing the learners to use their language resources and, thus, enhancing their linguistic abilities (Chauhan, 2004, 1). It means that it forces learners to experience language in operation. In addition, using drama techniques is exciting since it employs a multi-sensory approach to language acquisition by involving the participants physically, emotionally and linguistically (Gasparro \& Falleta, 2004).

According to Sun (2003), besides fun, employing drama in ESL/EFL classrooms would assist learners develop decoding skills, fluency, vocabulary, syntactic knowledge, discourse knowledge and metacognitive thinking. Moreover, it would increase motivation and reduce anxiety (Reig, 2009). Peregoy and Boyle (2008) claim that acting out stories and events would motivate learners to process and share information. They add that "Drama activities provide students with a variety of contextualized and scaffolded activities that gradually involve more participation and more oral proficiency; they are also non-threatening and a lot of fun" Peregoy and Boyle, 2008, 128). Furthermore, integrating drama would facilitate learning (Reig, 2009). Experiencing drama and dramatic activities would expand the vocabulary of the language learners because they not only learn by heart the new encountered words, but also they act them out (Sun, 2003). So it would help them acquire this vocabulary easier and faster. In addition, being engaged in drama activities would increase the learners' awareness of cultural aspects of the target culture (Gasparro \& Falleta, 2004). Moreover, drama activities would be used for teaching pronunciation effectively to include stress and intonation (Sasaki \& Kono, 2006; Gasparro \& Falleta, 2004). Alber \& Foil (22) conclude that drama activities could be an effective motivating instructional tool for learners.

Kerry-Moran (2006) defines readers theater as "a staged reading of a play or dramatic piece of work designed to entertain, inform, or influence" (p. 317). So drama would also improve the reading skills of the performers. Drama activities can also enhance the participants' writing skills. Peregoy and Boyle (2008) recommend a story retelling by the pupils after the teacher's reading and acting it out in a group. Crumpler and Schneider (2002) conducted a cross-study analysis of writing in a first grade classroom, where stories are read and acted out. The pupils were asked questions related to the content and the characters. The researchers conclude that drama and movement could be used to enhance literacy skills.

Wright et al (2007) states that in addition to motivation, drama allows learners to think in more sophisticated ways. It could be concluded that integrating drama in ESL/EFL classes would increase language learning, enhance motivation and reduce anxiety among learners.

Using drama and movement facilitates the brain to learn and to retain information since it is dynamically involved in exploring things, inquiring others and analyzing information. Royka (2002) asserts that drama activities can bring life to ESL/EFL classroom. Brain research suggests that movement may improve learning therefore, teachers are expected "to engage students in a great variety of postures, including walking, lying down, moving, learning against a wall or desk, perching or even squatting" (Jensen, 2000, p.34). In addition, active learning would be more fun and better remembered. Furthermore, it has been claimed that language learning is likely to happen with meaning and be student-centered (Sasaki \& Kono, 2006). The learner-centered approach of language teaching makes the experience personally fulfilling, which creates a student-participatory language learning experience (Gasparro \& Falleta, 2004).

Gaudert (1990) conducted a research study to investigate the use of drama activities in different settings and to 
different proficiency level ESL classes in Malaysia. Over 300 hundred teachers with a varied level of training and experience who teach low, intermediate and high level classes in urban as well as rural areas were involved in the research. The employed drama activities included improvisation, pantomime, role playing, and simulations. It has been found that drama techniques worked for most teachers. In addition, some of these techniques worked better in certain circumstances than others. Moreover, Gaudert (1990) concludes that drama activities are useful for motivating pupils, capturing their attention and arousing their creativity.

However, not many teachers are willing to adopt drama and drama activities in their instruction (Royka, 2002). For example, some would claim that they are not drama experts and others don't want to be silly in front of the students in the classroom. In addition, traditional teachers would claim that drama is fun and not a serious method for learning. Moreover, others may think that preparing for drama activities is time consuming. Furthermore, many schools lack drama resources. If they are available, they won't fit the ESL classrooms. Gaudert (1990) finds out that some teachers find it difficult to integrate drama in their instruction, and others are not willing to try theater activities because they feel that it requires a great deal of preparation. Also, other teachers objected because performing on the stage is emotionally demanding since it requires pupils to perform in front of others. Therefore, Gaudert (1990) concludes that convincing and training teachers to adopt drama activities in their classes is essential. For example, student teachers through their training should be shown how theater techniques would fit in the overall plan and curriculum and how would they meet their needs as well as their pupils'. In addition, pre-service teachers should be engaged in preparing theatre activities that suit the different levels of pupils.

\section{THE ATTEMPTS OF INTEGRATING DRAMA IN EFL INSTRUCTION}

Participating in the P.D.S (Professional Development Schools) program was an opportunity to work with the students closely in trying to expose them to a variety of teaching methods and approaches. According to Ariav and Emanuel (2003), working in the P.D.S. framework and accompanying the students at schools on a weekly basis enables pedagogical advisers to expose them to the school's atmosphere, environment and ecology as well as the different interactions between the administration and staff members. Moreover, it provides them the opportunity to be engaged in different school activities. Therefore, accompanying my students once a week for six hours enables me to provide them with emotional, professional as well as reflective support. Furthermore, it makes it possible and worthy to try out my personal mission, as a pedagogical adviser, of conceptual change of their personal perceptions of teaching as a long life experience of trial and error and belief in themselves and their abilities, and openess to innovative ideas and methods for effective teaching. Therefore, integrating drama was part of the annual plan and curriculum.

\section{PARTICIPANTS}

The participants of this modest project are third-year female Arab students who are majoring in teaching English as a foreign language at Beit Berl College. They practice teaching in a junior high school in an Arab town in the centre of Israel, accompanied by me, their pedagogical adviser once a week for five hours.. Besides the regular load of classroom observations and teaching, they are expected to be actively involved in school's projects and activities. Therefore, their adviser has time to encourage them to try innovative exciting ideas in their instruction despite the harsh reality of schools, which lack all fundamental infrastructure for practicing alternative methods of teaching. In fact, the classrooms are called "chalk and talk" because they lack most of the updated equipment for effective language learning (Abu Rass \& Holzman, 2010).In addition, the number of the pupils in classes is relatively large, around 40 pupils in each class.

\section{OBJECTIVES}

Besides the educational, physical, linguistic, emotional and intellectual benefits of employing drama in EFL classrooms that have been mentioned in the introduction, the pedagogical adviser had her own pedagogical objectives, which are the following:

1) To break the routine of teaching English frontally and traditionally

2) To have fun and a pleasant teaching practice experience

3) To provide opportunities for experiencing innovative ideas that could be used in the future

4) To have a first hand experience in witnessing the language improvement among the participants

5) To create an atmosphere of cooperation between student teachers and their trainees

\section{CONDUCTING THE THEATER WORKSHOP}

To conduct the theater workshop, the student teachers and their trainers were expected to choose the potential participants. Therefore, they met several times with the coordination of the pedagogical advisor trying to detect the most appropriate candidates. The pedagogical adviser was eager to involve not only the most advanced pupils in class, but also the average and sometimes the below average ones; however, neither the student teachers nor the trainers wanted that. Finally, pupils with different abilities were chosen to take the roles in the play matching between their linguistic abilities in English and their roles in the plays. For example, the most advanced pupils were given the most demanding 
roles in terms of language and movement, and the least advanced ones were chosen to play roles that are less demanding.

In the two attempts, a very modest budget was assigned by the school principals, who were very enthusiastic to see the pupils performing in English on the stage, to purchase simple things such as stationary paper, colors, brushes and other necessary simple tools and equipment. The stages were decorated by the trainees themselves with the help of some pupils.

For the first attempt, costumes were collected from the student teachers, their adviser, the trainers and the pupils themselves. However, in the second year, the costumes were stitched by a professional dress maker. In both cases, the stages were also decorated by the student teachers with the help of the pupils. In the first year, the decoration was simple. However, the student teachers were more than eager to decorate the stage in the second year and to match it with the real one.

Nine trainees participated in the project in the first year. Although three were assigned to do the rehearsal and follow the development of the performance, the nine students finally participated encouraging the pupils to learn their roles by heart and to coordinate their roles with appropriate movements. In the second year, 8 trainees took part in the project. Each one was responsible for training a pupil to learn his role, match his movements and do the rehearsal. The transcripts were downloaded from the internet and the language was modified to help the pupils learn their roles.

The first play, Joseph, was acted on the stage in May 21, 2008 as part of the English Day in the school, which has the title "Historical Perspectives and their Effects on Modern Egypt". The school is in an Arab town adjacent to the Academic College Beit Berl. Besides the play, the student teachers helped two advanced pupils to run a travel agency. The travel agents prepared vacation packages for potential tourists to Egypt. All the conversations were held in English. In addition, some language games were prepared with the objective of helping pupils learn more facts about Egypt and play at the same time.

The second play, The Lion King, was performed in May 23, 2009 in another junior high school in the same town. This play was specifically chosen because some of the student teachers participated in an educational tour to London in 2008 and watched the play there.

\section{OBSERVATIONS AND REFLECTIONS}

Despite the limited financial sources, the principals of the two schools were more eager to help and provide a modest sum for decorating the stages. I have noticed that the student teachers and the participating pupils have developed close social relations. They became closer and cared about each other. The most important observed behavior was the pupils' self -discipline. They became more attentive and cooperative in the classroom and showed respect when the trainees delivered their lessons. It is important to note that the pupils were highly motivated. They learned their roles faster than it was expected.

The following are the reflections of the student teachers regarding the first play. Five out of the nine trainees reflected on the English Day and their role preparing the pupils for the play.

The idea for the English day was brought up by you. We were a little bit apprehensive of that day because this was the first time we work on such a project.

Even though my hands were full, I also helped with the Play "Joseph and his Brothers" a lot. I urged both the student teachers and the pupils to rehearse, work, and prepare costumes and props. Even though it was tiring, I enjoyed helping and assisting. I believe that I have contributed a lot to the preparing for the English day. The English day itself was every successful due to the hard work and unity that we all invested, pedagogical adviser, student-teachers and pupils; to the pupils work and performances, and most importantly to your support for us and for our work. You provided us with the tools and support that we needed and the outcome was a great success. Our English day was the talk of the students and instructors. It is always great to feel appreciated and valued for the hard work.

I don't forget that we worked very hard in the English day. In English day, we achieved the educational objectives through the use of different domains. Moreover, this day encouraged communication between students with each other and with us.

My expectations for this day were a little bit negative but when on the same day, I realized that the students enjoyed it a lot. It proved that English days support learning in the school. They are engaging and motivating and provide an insight into the main topic to be considered before.

I don't forget that our pedagogical adviser played a key role in integrating and planning. We chose students from different levels and grades; we gave them a specific show or activity that they have to work on for that day like "Travel Agency" and "the Play".

There is no doubt that there was noise during the English day but it is ok as a first time. To be honest, I was glad that we able to organize and to prepare for this day. The other great feeling is the feeling that I am done with it. I felt as if I was carrying a mountain on my shoulders and suddenly it slipped a way leaving beheaded it a feeling of relief.

Regarding the English day, I took it very seriously since I was very excited to make it a huge success. I was in a continuous contact with the girls I worked with mainly through e-mails and sometimes via telephone. I used to force them to work despite the several difficulties: taking them out of class, test days...etc.

Concerning the English day, you know how tiring the work was specially with the girls of my group whom their 
contribution and cooperation was not sufficient. I sent them many e-mails to finish the work but they always had excuses.

I also wanted to talk about the play we did with the pupils we worked hard on writing the script I mailed M. a lot of times in order to make sure that its correct and suitable to the pupils I also was in contact with the pupils by phone and also by the email. In addition to that in our vacation we came twice to the school and practiced the play with the pupils. This year I was motivated to work hard.

Two student teachers from the second group addressed their participation preparing the pupils for performing play in their reflections.

I enjoyed the experience of having rehearsals for the play that we sat weekly and listened to the pupils practicing their roles till they got to the perfect performance in the presentation day.

One of the things we worked on this year in our practical work was our project of preparing a scene from the movie "The Lion King". To be honest, this really had taken so much effort to be done, but it really made us all work so hard and we felt so responsible on preparing every thing and doing the best we can. Its was our responsibility to make the students prepared for their presentation, it was also important to create the set of the play so we worked hard in preparing pictures and drawings to create a beautiful scene. It was beautiful put and everyone like the outcome.

\section{CONCLUSION}

Based on the above reflections, it could be concluded that the student teachers were apprehended and hesitant at the beginning to be involved in the project of integrating drama in EFL instruction. However, they enjoyed the experience although it was tiring. It has also been indicated by one of the student teachers that preparing the pupils for the play improved the communication between them as trainees and pupils. Their relations became closer.

There is a need for a follow up research to check if the graduates are really engaged in extra curriculum activities and are willing to work hard and to try alternative innovative ideas that would foster English language learning through fun. There is a need to involve these graduates in a future research study to verify if they implement drama and dramatic activities in their instruction. If it is so, the research should examine the improvement of the pupils in terms of pronunciation, vocabulary and writing.

\section{REFERENCES}

[1] Abu Rass, R. \& Holzman, S. (2010). Children's literature in traditional Arab schools for teaching English as a foreign language. English Language Teaching, 3 (1), 64-72.

[2] Alber, S. R. \& Foil, C. R. (2003). Drama activities that promote and extend students' vocabulary proficiency. Intervention in School and Clinic, 39 (1), 22-29.

[3] Chauhan, V. (2004). Dramatechniques for teaching English. The Internet TESL Journal, 10 (10).

[4] Crumpler, T. \& Schneider, J. (2002). Writing with their whole being: a cross study analysis of children's writing from five classrooms using process drama. Research in Drama Education: The Journal of Applied Theatre, 7 (1), 61-79.

[5] Emanuel, D. (2005). Perception of the pedagogical advisor's role: three points of view. Browse month internship training program for pedagogical studies. Position Paper No. 2. Tel Aviv: MOFET Institute

[6] Gasparro, M. \& Falleta, B. (2004). Creating drama with poetry: teaching English as a second language through dramatization and improvisation. Retrieved on Feb. 24, 2010 from www.cal.org/resources/digest/gaspar01.html.

[7] Gaudart, H. (1990). Using drama techniques in language teaching. Eric Document, Ed 366197. Retrieved on Feb. 24, 2010 from www.eric.ed.gov/ERICors/data/ericdocs 2 sq/...

[8] Jensen, E. (2000). Moving with the brain in mind. Educational Leadership, 58 (3), 34-37.

[9] Peregoy, S. \& Boyle, O. (2008). Reading, writing and learning in ESL. (5th ed.). Boston: Pearson.

[10] Reig, S. (2009). Using drama and movement to enhance English language learners' literacy development. Journal of Instructional Psychology. Retrieved on Feb. 24, 2010 from www.thefreelibrary.com/Using+drama+and+movement+to+enhance+English+1

[11] Royka, J. G. (2002). Overcoming the fear of using drama in English language teaching. The Internet TESL Journal, (8) 6.

[12] Sasaki, M. \& Kono, M. (2006). Integrating drama performance and debate-style speech performance in English language teaching: paralleled collaborative teaching. Akita English Studies, 49, 46-56.

[13] Sun, P. (2003). Using drama and theater to promote literacy development: some basic classroom applications. The Clearing House of Reading, English and Communication Digest \#187. Retrieved on February 24, 2010 from www.indiana.edu/ reading/ieo/digest/d168.html.

[14] Wright, C., Bacigalupa, C., Black, T. \& Burton, M. (2007). Windows into children's thinking: A guide to storytelling and dramatization. Early Childhood Education Journal, 35, 363-369.

Ruwaida Abu Rass is a teacher educator in the Academic Institute for Arab Teacher Training at the Academic College Beit Berl in the central of Israel. She pursued her doctoral degree in ESL/EFL at the University of Arizona from 1992-1997. Since her graduation in 1997, she works in the English Department at the Academic Institute for Arab Teacher Training as a lecturer and a pedagogical adviser. She headed the English Department from 2004 through 2008. Dr. Abu Rass is interested in ESL/EFL studies and teacher education. Besides her professional career, she served as a member of the Council of the Second Authorities for Broadcasting representing one million and three hundred Palestinian Arabs in Israel. 